National and Global Petroleum Assessment

\title{
Assessment of Continuous Gas Resources in the Horn River Basin, Cordova Embayment, and Liard Basin, Canada, 2019
}

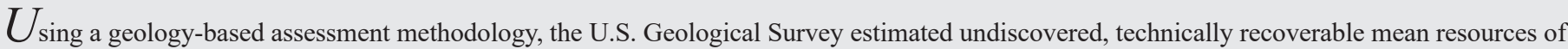
135.4 trillion cubic feet of continuous gas in Devonian-Mississippian shales in the Horn River Basin, Cordova Embayment, and Liard Basin of Canada.

\section{Introduction}

The U.S. Geological Survey (USGS) quantitatively assessed the potential for undiscovered, technically recoverable continuous, or unconventional, gas resources in Devonian-Mississippian organic-rich shales in the Horn River Basin, Cordova Embayment, and Liard Basin of the Alberta Basin Province in Canada (fig. 1). From the Middle Devonian to Early Mississippian, carbonate platforms and adjacent deepwater

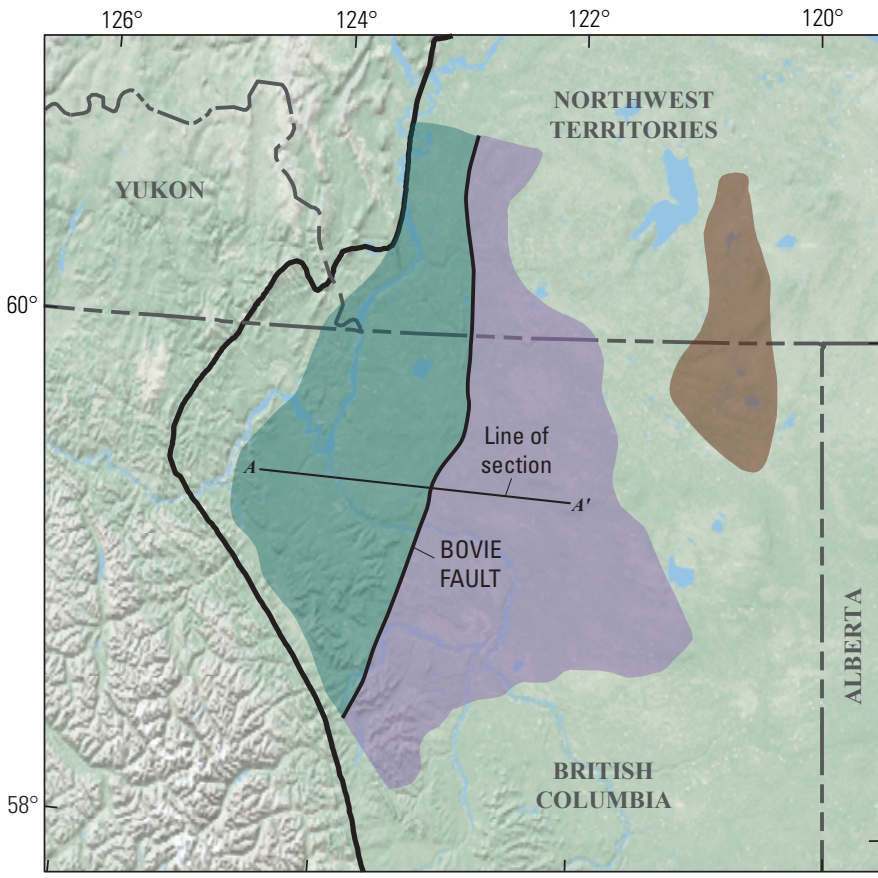

Base map from U.S. Department of the Interior National Park Service

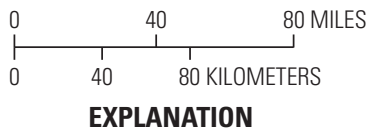

Horn River Basin Evie Shale Gas AU, Horn River Basin Muskwa-Otter Park Shale Gas AU, and Horn River Basin Exshaw Shale Gas AU

Cordova Embayment Evie Shale Gas AU, Cordova Embayment Muskwa-Otter Park Shale Gas AU, and Cordova Embayment Exshaw Shale Gas AU

Liard Basin Besa River Shale Gas AU

Alberta Basin Province boundary (part)

Figure 1. Map showing the seven continuous assessment units (AUs) in the Horn River Basin, Cordova Embayment, and Liard Basin of the Alberta Basin Province, Canada. basins were located along the western passive margin of North America, with open-marine conditions to the west and northwest. Carboniferous through Triassic subduction and collision of several terranes along the western margin of North America resulted in a long period of uplift, erosion, or nondeposition. The Late Jurassic development of an eastverging, fold/thrust belt and foreland basin (Price, 1994), and its continued subsidence into the Late Cretaceous through Paleogene, provided the necessary burial for adequate thermal maturity for oil and gas generation (Creaney and Allan, 1990; Fowler and others, 2001).

This study focuses on the assessment of organic-rich shales that were deposited in the deep, oxygen-deficient basins adjacent to the carbonate platforms (Ross and Bustin, 2008; Chen and Hannigan, 2016; Ayranci and others, 2018). These shales include the Evie Member and Otter Park Member of the Horn River Formation, the Muskwa Formation, and the Exshaw Formation in the Horn River Basin (British Columbia Oil and Gas Commission, 2014); Evie Member, Otter Park Member, Muskwa Formation, and Exshaw Formation in the Cordova Embayment; and the Besa River Formation in the Liard Basin (fig. 2). The Besa River Formation is equivalent to the stratigraphic interval from the Evie Member through the Exshaw Formation. Several hundred meters of Middle Devonian to Mississippian shales were deposited within these basins, but organic-rich shales only constitute part of the total shale thickness. Placing the shales in a sequence-stratigraphic context defines the intervals of organic-rich shales for the assessment (Jonk and others, 2013; Kam and others, 2015; Ayranci and others, 2018). The Evie Member represents a transgressive shale deposited across the underlying Keg River carbonate platform and is a distal, condensed, low-clay percentage siliceous shale that is a primary target for shale-gas development. The overlying Otter Park Member is a complex stratigraphic unit. The lower and upper parts of the Otter Park Member are lowstand wedges that are organically lean and are not petroleum source rocks. The middle part of the Otter Park Member is a transgressive, organic-rich shale that drapes the lowstand wedge and is a source rock. The Muskwa Formation, like the Evie Member, is an organicrich transgressive shale that thins landward. The Exshaw Formation, an equivalent to the Bakken Formation, is a transgressive organic-rich shale (Smith and Bustin, 2000). The clinoform unit of the Fort Simpson Formation (and equivalent strata of the Besa River Formation) is an organic-lean interval that is generally not a source rock, but opinions vary as to source rock potential (Ross and Bustin, 2008; National Energy Board, 2016).

The Evie Member is a specific target shale reservoir for horizontal drilling. However, because fractures within the Otter Park Member propagate up into the Muskwa Formation (Kam and others, 2015), the Otter Park Member and Muskwa Formation shales together form a horizontal drilling target (Virués and others, 2013; Mack and others, 2016; Teklu and others, 2018; Urban-Rascon and others, 2018; Agar and others, 2019). The overlying Exshaw Formation, like the Evie Member, is a single horizontal drilling target. The importance of natural and induced fractures to the production of shale gas in these 


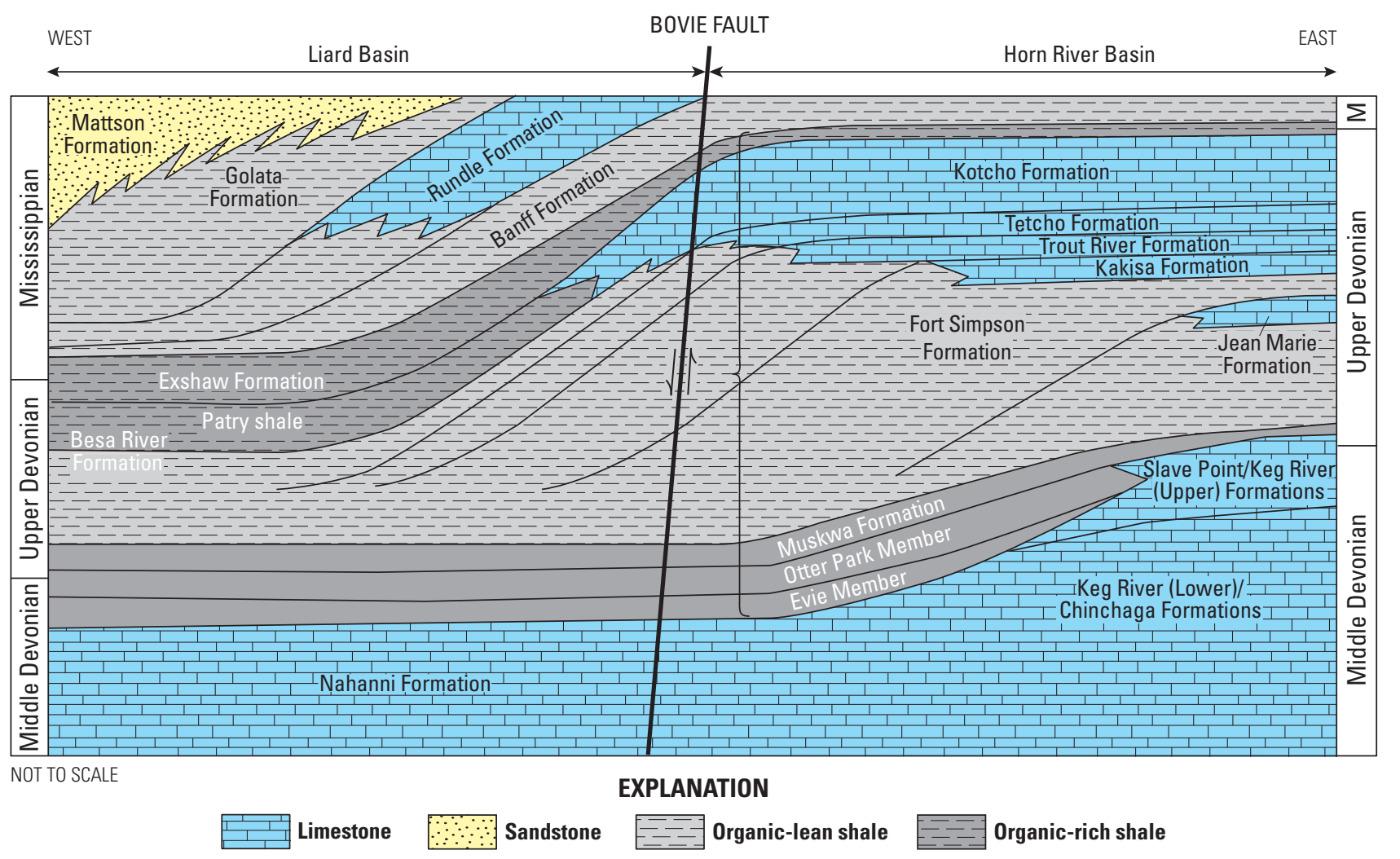

Figure 2. Schematic cross section showing stratigraphic relationships between the Horn River Basin and Liard Basin. The Bovie Fault separates the basins. Modified from National Energy Board (2016).

units has been the subject of intensive study (Reynolds and Munn, 2010; Rogers and others, 2010; Novlesky and others, 2011; EhligEconomides and others, 2012; Khan and others, 2012; Dong and others, 2017; Yang and others, 2018; Agar and others, 2019). These studies have shown that the organic-rich shales are lithologically and structurally heterogeneous, which can affect spacing, length, orientation, and conductivity of natural and induced fractures and can also affect shale-gas production.

\section{Total Petroleum Systems and Assessment Units}

The USGS defined a Middle-Upper Devonian Total Petroleum System (TPS) encompassing the (1) Horn River Basin Evie Shale Gas Assessment Unit (AU), (2) Horn River Basin Muskwa-Otter Park Shale Gas AU, (3) Cordova Embayment Evie Shale Gas AU, and the (4) Cordova Embayment Muskwa-Otter Park Shale Gas AU. Shales of the Evie Member, Otter Park Member, Muskwa Formation, and their equivalents are generally within the dry-gas generation window in these three basins (Ross and Bustin, 2008; Dong and Harris, 2013; Chen and Hannigan, 2016; Dong and others, 2017, 2018); so, standard geochemical parameters such as total organic carbon and hydrogen index are of limited use because of the high level of thermal alteration of organic matter. The geologic model for the Middle-Upper Devonian TPS is for oil and gas to have been generated from Middle to Late Devonian source rocks; oil was cracked to gas from Late CretaceousPaleogene foredeep burial, and gas was partially retained within the shales following expulsion and migration.

The USGS defined an Upper Devonian-Mississippian TPS to encompass the Horn River Basin Exshaw Shale Gas AU and the Cordova Embayment Exshaw Shale Gas AU. The Upper Devonian-Lower
Mississippian Exshaw Formation in the Horn River Basin and Cordova Embayment is equivalent to the organic-rich shales in the upper part of the Besa River Formation in the Liard Basin (Ross and Bustin, 2008). The geologic model is for gas to have been retained within the shales following generation, migration, and structural deformation.

The Middle Devonian-Mississippian TPS was defined in the Liard Basin to include potential gas resources within organic-rich shales of the Besa River Formation (fig. 2). The Liard Basin Besa River Shale Gas AU was defined within this TPS. The Liard Basin is located on the western downdropped side of the regional Bovie Fault, and the Besa River Formation shales have been buried more than several hundred meters compared to the Horn River Basin (National Energy Board, 2016). Deeper burial and high thermal maturity in Besa River Formation shales in the Liard Basin may have adversely affected the quantities of recoverable gas.

Assessment input data are summarized in table 1. Input data for distributions of estimated ultimate recovery and drainage area were based on Chen and Hannigan (2016) and Yousefzadeh and others (2016).

\section{Undiscovered Resources Summary}

The USGS quantitatively assessed continuous gas resources in seven AUs in the Horn River Basin, Cordova Embayment, and Liard Basin of the Alberta Basin Province in Canada (table 2). For undiscovered, technically recoverable continuous gas resources, the estimated mean cumulative resources are 135,350 billion cubic feet of gas (BCFG), or 135.4 trillion cubic feet of gas, with an F95-F5 fractile range from 38,096 to 254,252 BCFG and 335 million barrels of natural gas liquids (MMBNGL) with an F95-F5 fractile range from 83 to 710 MMBNGL. Of the potential continuous gas resources of $135,350 \mathrm{BCFG}$, about $107,036 \mathrm{BCFG}$ - or 79 percent - is estimated to be in the Horn River Basin. 
Table 1. Key input data for seven continuous assessment units in the Horn River Basin, Cordova Embayment, and Liard Basin of the Alberta Basin Province in Canada.

[Well drainage area, success ratio, and estimated ultimate recovery are defined partly using U.S. shale-gas analogs. The average estimated ultimate recovery input is the minimum, median, maximum, and calculated mean. Gray shading indicates not applicable. AU, assessment unit; \%, percent; EUR, estimated ultimate recovery (per well); BCFG, billion cubic feet of gas]

\begin{tabular}{|c|c|c|c|c|c|c|c|c|}
\hline \multirow{2}{*}{$\begin{array}{l}\text { Assessment input data- } \\
\text { Continuous AUs }\end{array}$} & \multicolumn{4}{|c|}{ Horn River Basin Evie Shale Gas AU } & \multicolumn{4}{|c|}{ Horn River Basin Muskwa-Otter Park Shale Gas AU } \\
\hline & Minimum & Mode & Maximum & $\begin{array}{c}\text { Calculated } \\
\text { mean }\end{array}$ & Minimum & Mode & Maximum & $\begin{array}{c}\text { Calculated } \\
\text { mean }\end{array}$ \\
\hline Potential production area of AU (acres) & 1,000 & $2,368,000$ & $4,736,000$ & $2,368,333$ & 1,000 & $2,368,000$ & $4,736,000$ & $2,368,333$ \\
\hline Average drainage area of wells (acres) & 80 & 120 & 160 & 120 & 80 & 120 & 160 & 120 \\
\hline Area untested in $\mathrm{AU}(\%)$ & 90 & 94 & 98 & 94 & 85 & 90 & 95 & 90 \\
\hline Success ratio $(\%)$ & 40 & 60 & 80 & 60 & 50 & 70 & 90 & 70 \\
\hline Average EUR (BCFG) & 2 & 4 & 6 & 4.067 & 2 & 4 & 6 & 4.067 \\
\hline AU probability & 1.0 & & & & 1.0 & & & \\
\hline \multirow{2}{*}{$\begin{array}{l}\text { Assessment input data- } \\
\text { Continuous AUs }\end{array}$} & \multicolumn{4}{|c|}{ Cordova Embayment Evie Shale Gas AU } & \multicolumn{4}{|c|}{ Cordova Embayment Muskwa-Otter Park Shale Gas AU } \\
\hline & Minimum & Mode & Maximum & $\begin{array}{c}\text { Calculated } \\
\text { mean }\end{array}$ & Minimum & Mode & Maximum & $\begin{array}{c}\text { Calculated } \\
\text { mean }\end{array}$ \\
\hline Potential production area of AU (acres) & 1,000 & 502,000 & $1,004,000$ & 502,333 & 1,000 & 502,000 & $1,004,000$ & 502,333 \\
\hline Average drainage area of wells (acres) & 80 & 120 & 160 & 120 & 80 & 120 & 160 & 120 \\
\hline Area untested in $\mathrm{AU}(\%)$ & 99 & 100 & 100 & 99.7 & 94 & 96 & 98 & 96 \\
\hline Success ratio $(\%)$ & 10 & 50 & 90 & 50 & 40 & 60 & 80 & 60 \\
\hline Average EUR (BCFG) & 2 & 4 & 6 & 4.067 & 2 & 4 & 6 & 4.067 \\
\hline AU probability & 1.0 & & & & 1.0 & & & \\
\hline \multirow{2}{*}{$\begin{array}{l}\text { Assessment input data- } \\
\text { Continuous AUs }\end{array}$} & \multicolumn{4}{|c|}{ Horn River Basin Exshaw Shale Gas AU } & \multicolumn{4}{|c|}{ Cordova Embayment Exshaw Shale Gas AU } \\
\hline & Minimum & Mode & Maximum & $\begin{array}{c}\text { Calculated } \\
\text { mean }\end{array}$ & Minimum & Mode & Maximum & $\begin{array}{c}\text { Calculated } \\
\text { mean }\end{array}$ \\
\hline Potential production area of AU (acres) & 1,000 & $2,368,000$ & $4,736,000$ & $2,368,333$ & 1,000 & 502,000 & $1,004,000$ & 502,333 \\
\hline Average drainage area of wells (acres) & 80 & 120 & 160 & 120 & 80 & 120 & 160 & 120 \\
\hline Area untested in $\mathrm{AU}(\%)$ & 100 & 100 & 100 & 100 & 100 & 100 & 100 & 100 \\
\hline Success ratio $(\%)$ & 10 & 50 & 90 & 50 & 10 & 50 & 90 & 50 \\
\hline Average EUR (BCFG) & 0.1 & 1 & 2 & 1.036 & 0.1 & 1 & 2 & 1.036 \\
\hline AU probability & 1.0 & & & & 0.9 & & & \\
\hline \multirow{2}{*}{$\begin{array}{c}\text { Assessment input data- } \\
\text { Continuous AUs }\end{array}$} & \multicolumn{4}{|c|}{ Liard Basin Besa River Shale Gas AU } & \multirow{7}{*}{\multicolumn{4}{|c|}{$\begin{array}{l}\text { For More Information } \\
\text { Assessment results are also available } \\
\text { at the USGS Energy Resources Program } \\
\text { website at https://energy.usgs.gov. }\end{array}$}} \\
\hline & Minimum & Mode & Maximum & $\begin{array}{c}\text { Calculated } \\
\text { mean }\end{array}$ & & & & \\
\hline Potential production area of AU (acres) & 1,000 & $1,836,000$ & $3,673,000$ & $1,836,667$ & & & & \\
\hline Average drainage area of wells (acres) & 80 & 120 & 160 & 120 & & & & \\
\hline Area untested in AU (\%) & 100 & 100 & 100 & 100 & & & & \\
\hline Success ratio $(\%)$ & 10 & 50 & 90 & 50 & & & & \\
\hline Average EUR (BCFG) & 0.1 & 1 & 2 & 1.036 & & & & \\
\hline AU probability & 1.0 & & & & & & & \\
\hline
\end{tabular}

Table 2. Results for seven continuous assessment units in the Horn River Basin, Cordova Embayment, and Liard Basin of the Alberta Basin Province in Canada.

[Results shown are fully risked estimates. F95 represents a 95-percent chance of at least the amount tabulated; other fractiles are defined similarly. Gray shading indicates not applicable. BCFG, billion cubic feet of gas; NGL, natural gas liquids; MMBNGL, million barrels of natural gas liquids]

\begin{tabular}{|c|c|c|c|c|c|c|c|c|c|c|}
\hline \multirow{3}{*}{$\begin{array}{l}\text { Total petroleum systems and } \\
\text { assessment units (AUs) }\end{array}$} & \multirow{3}{*}{$\begin{array}{c}\text { AU } \\
\text { proba- } \\
\text { bility }\end{array}$} & \multirow{3}{*}{$\begin{array}{c}\text { Accum- } \\
\text { ulation } \\
\text { type }\end{array}$} & \multicolumn{8}{|c|}{ Total undiscovered resources } \\
\hline & & & \multicolumn{4}{|c|}{ Gas (BCFG) } & \multicolumn{4}{|c|}{ NGL (MMBNGL) } \\
\hline & & & F95 & F50 & F5 & Mean & F95 & F50 & F5 & Mean \\
\hline \multicolumn{11}{|c|}{ Middle-Upper Devonian Total Petroleum System } \\
\hline Horn River Basin Evie Shale Gas AU & 1.0 & Gas & 13,680 & 44,144 & 82,957 & 45,742 & 29 & 97 & 215 & 107 \\
\hline Horn River Basin Muskwa-Otter Park Shale Gas AU & 1.0 & Gas & 15,286 & 49,592 & 92,273 & 51,111 & 32 & 109 & 242 & 119 \\
\hline Cordova Embayment Evie Shale Gas AU & 1.0 & Gas & 2,092 & 7,842 & 17,579 & 8,565 & 4 & 17 & 45 & 20 \\
\hline Cordova Embayment Muskwa-Otter Park Shale Gas AU & 1.0 & Gas & 2,906 & 9,519 & 17,855 & 9,861 & 6 & 21 & 47 & 23 \\
\hline \multicolumn{11}{|c|}{ Upper Devonian-Mississippian Total Petroleum System } \\
\hline Horn River Basin Exshaw Shale Gas AU & 1.0 & Gas & 2,302 & 9,042 & 21,991 & 10,183 & 7 & 28 & 81 & 34 \\
\hline Cordova Embayment Exshaw Shale Gas AU & 0.9 & Gas & 0 & 1,747 & 4,546 & 1,941 & 0 & 5 & 17 & 6 \\
\hline \multicolumn{11}{|c|}{ Middle Devonian-Mississippian Total Petroleum System } \\
\hline Liard Basin Besa River Shale Gas AU & 1.0 & Gas & 1,830 & 7,084 & 17,051 & 7,947 & 5 & 22 & 63 & 26 \\
\hline Total undiscovered continuous resources & & & 38,096 & 128,970 & 254,252 & 135,350 & 83 & 299 & 710 & 335 \\
\hline
\end{tabular}




\section{References Cited}

Agar, S.M., Li, W., Goteti, R., Jobe, D., and Zhang, S., 2019, Bayesian artificial intelligence for geologic prediction-Fracture case study, Horn River Basin: Bulletin of Canadian Petroleum Geology, v. 67, no. 3, p. 141-184.

Ayranci, K., Harris, N.B., and Dong Tian, 2018, Sedimentological and ichnological characterization of the Middle to Upper Devonian Horn River Group, British Columbia, Canada-Insights into mudstone depositional conditions and processes below storm wave base: Journal of Sedimentary Research, v. 88, no. 1, p. 1-23.

British Columbia Oil and Gas Commission, 2014, Horn River Basin unconventional shale gas play atlas: British Colombia Oil and Gas Commission, 27 p., accessed January 27, 2020, at https://www.bcogc.ca/node/11238/download.

Chen, Z., and Hannigan, P., 2016, A shale gas resource potential assessment of Devonian Horn River strata using a well-performance method: Canadian Journal of Earth Sciences, v. 53 , no. 2 , p. $156-167$.

Creaney, S., and Allan, J., 1990, Hydrocarbon generation and migration in the Western Canada sedimentary basin, in Brooks, J., ed., Classic petroleum provinces: The Geological Society of London, Special Publication 50, p. 189-202.

Dong Tian, and Harris, N.B., 2013, Pore size distribution and morphology in the Horn River Shale, Middle and Upper Devonian, northeastern British Columbia, Canada, chap. 8 of Camp, W.K., Diaz, E., and Wawak, B., eds., Electron microscopy of shale hydrocarbon reservoirs: American Association of Petroleum Geologists, Memoir No. 102, p. 67-79.

Dong Tian, Harris, N.B., and Ayranci, K., 2018, Relative sea-level cycles and organic matte accumulation in shales of the Middle and Upper Devonian Horn River Group, northeastern British Columbia, Canada-Insights into sediment flux, redox conditions, and bioproductivity: Geological Society of America Bulletin, v. 130, no. 5-6, p. 859-880.

Dong Tian, Harris, N.B., Ayranci, K., and Yang Sheng, 2017, The impact of rock composition on geomechanical properties of a shale formation-Middle and Upper Devonian Horn River Group shale, northeast British Columbia, Canada: American Association of Petroleum Geologists Bulletin, v. 101, no. 2, p. 177-204.

Ehlig-Economides, C.A., Ahmed, I.A., Apiwathanasorn, S., Lightner, J.H., Song, B., Vera, F.E.V., Han, X., and Zhang, Y., 2012, Stimulated shale volume characterization-Multiwell case study from the Horn River Shale-II. Flow perspective, in Society of Petroleum Engineers Annual Technical Conference and Exhibition, San Antonio, Tex., October 8-10, 2012, Proceedings: Society of Petroleum Engineers, SPE-159546-MS, 12 p., accessed January 30, 2020, at https://www.onepetro.org/conference-paper/SPE-159546-MS.

Fowler, M.G., Stasiuk, L.D., Hearn, M., and Obermajer, M., 2001, Devonian hydrocarbon source rocks and their derived oils in the Western Canada Sedimentary Basin: Bulletin of Canadian Petroleum Geology, v. 49, no. 1, p. 117-148.

Jonk, R., Allen, J., Magennis, L., Potma, K., and Wamsteeker, M., 2013, Constructing meaningful geologic models of shale gas systems-An example from the Horn River Basin, Canada, in Unconventional Resources Technology Conference, Denver, Colo., August 12-14, 2013, Proceedings: Society of Petroleum Engineers, American Association of Petroleum Geologists, and Society of Exploration Geophysicists, URTeC 1578553, 6 p., accessed January 22, 2021, at https:/onepetro.org/URTECONF/ proceedings-abstract/13URTC/All-13URTC/URTEC-1578553-MS/148892.

Kam, P., Nadeem, M., Novlesky, A., Kumar, A., and Omatsone, E.N., 2015, Reservoir characterization and history matching of the Horn River Shale-An integrated geoscience and reservoir-simulation approach: Society of Petroleum Engineers, Journal of Canadian Petroleum Technology, v. 54, no. 6, SPE-171611-PA, p. 475-488, accessed January 22, 2021, at https://onepetro.org/JCPT/article-abstract/54/06/475/207776/ReservoirCharacterization-and-History-Matching-of?redirectedFrom=fulltext.

Khan, S., Ansari, S.A., Nader, K., and Han, H., 2012, Understanding shale heterogeneityKey to minimizing drilling problems in Horn River Basin, in International Association of Drilling Contractors/Society of Petroleum Engineers Drilling Conference and Exhibition, San Diego, Calif., March 6-8, 2012, Proceedings: Society of Petroleum Engineers, SPE-151752-MS, 11 p., accessed January 22, 2021, at https://onepetro.org/SPEDC/ proceedings-abstract/12DC/All-12DC/SPE-151752-MS/156638.

Mack, M., Maxwell, S.C., and Lee, B.T., 2016, Microseismic geomechanical optimization of hydraulic fracturing in the Horn River Basin, in Unconventional Resources Technology Conference (URTeC), San Antonio, Tex., August 1-3, 2016, Proceedings: Society of Petroleum Engineers, American Association of Petroleum Geologists, and Society of Exploration Geophysicists, URTeC 2430012, 9 p., accessed January 22, 2021, at https://library.seg.org/doi/abs/10.15530/urtec-2016-2430012.

National Energy Board, 2016, The unconventional gas resources of Mississippian-Devonian shales in the Liard Basin of British Columbia, the Northwest Territories, and YukonEnergy Briefing Note: National Energy Board [now the Canada Energy Regulator], British Columbia Oil and Gas Commission, British Columbia Ministry of Natural Gas Development, Northwest Territories Geological Survey, and Yukon Geological Survey, 16 p., accessed January 22, 2021, at https://www.cer-rec.gc.ca/nrg/sttstc/ntrlgs/rprt/ ltmtptntlbcnwtkn2016/index-eng.html.
Novlesky, A., Kumar, A., and Merkle, S., 2011, Shale gas modeling workflow_From microseismic to simulation-A Horn River case study, in Canadian Unconventional Resources Conference, Calgary, Alberta, Canada, November 15-17, 2011, Proceedings: Society of Petroleum Engineers, SPE-148710-MS, 24 p., accessed January 22, 2021, at https://onepetro.org/SPEURCC/proceedings-abstract/11CURC/All-11CURC/SPE$148710-\mathrm{MS} / 150549$

Price, R.A., 1994, Cordilleran tectonics and the evolution of the Western Canada Sedimentary Basin, chap. 2 of Mossop, G.D., and Shetsen, I., comps., Geological atlas of the Western Canada Sedimentary Basin: Canadian Society of Petroleum Geologists and Alberta Research Council, p. 13-24.

Reynolds, M.M., and Munn, D.L., 2010, Development update for an emerging shale gas giant field - Horn River Basin, British Columbia, Canada, in Unconventional Gas Conferences, Pittsburgh, Penn., February 23-25, 2010, Proceedings: Society of Petroleum Engineers, SPE-130103, 17 p., accessed January 22, 2021, at https://onepetro.org/SPEGTS/ proceedings-abstract/10UGC/All-10UGC/SPE-130103-MS/107747.

Rogers, S., Elmo, D., Dunphy, R., and Bearinger, D., 2010, Understanding hydraulic fracture geometry and interactions in the Horn River Basin through DFN and numerical modeling, in Canadian Unconventional Resources Conference, Calgary, Alberta, Canada, October 19-21, 2010, Proceedings: Society of Petroleum Engineers, CSUG/SPE-137488, 13 p., accessed January 22, 2021, at https://onepetro.org/SPEURCC/proceedingsabstract/10CURIPC/All-10CURIPC/SPE-137488-MS/104556.

Ross, D.J.K., and Bustin, R.M., 2008, Characterizing the shale gas resource potential of Devonian-Mississippian strata in the Western Canada Sedimentary Basin-Application of an integrated formation evaluation: American Association of Petroleum Geologists Bulletin, v. 92, no. 1, p. 87-125.

Smith, M.G., and Bustin, R.M., 2000, Late Devonian and Early Mississippian Bakken and Exshaw Black Shale source rocks, Western Canada sedimentary basin-A sequence stratigraphic interpretation: American Association of Petroleum Geologists Bulletin, v. 84 , no. 7 , p. $940-960$.

Teklu, T.W., Park Daejin, Jung Hoiseok, and Miskimins, J.L., 2018, Integrated rock characterization of a shale gas field in the Horn River Basin, Canada, in Unconventional Resources Technology Conference (URTeC), Houston, Tex., July 23-25, 2018, Proceedings: Society of Petroleum Engineers, American Association of Petroleum Geologists, and Society of Exploration Geophysicists, URTeC 2880467, 31 p., accessed January 22, 2021, at https://onepetro.org/URTECONF/proceedings-abstract/18URTC/ 1-18URTC/D013S012R004/157339.

Urban-Rascon, E., Yousefzadeh, A., Virués, C.J., and Aguilera, R., 2018, Evolution and evaluation of SRV in shale gas reservoirs-An application in the Horn River Shale of Canada: Society of Petroleum Engineers, SPE Reservoir Evaluation and Engineering, v. 21, no. 4, SPE-185609-PA, p. 889-906, accessed January 22, 2021, at https://onepetro.org/REE/ article-abstract/21/04/889/206674/Evolution-and-Evaluation-of-SRV-in-Shale-Gas? redirectedFrom=fulltexthttps.

Virués, C., Chin, A., and Anderson, D., 2013, Application of rate transient analysis workflow in unconventional reservoirs - Horn River shale gas case study, in Unconventional Resources Conference and Exhibition-Asia Pacific, Brisbane, Australia, November 11-13, 2013, Proceedings: Society of Petroleum Engineers, SPE-167042, 24 p., accessed January 22, 2021, at https:/onepetro.org/SPEURCE/proceedingsabstract/13URCE/All-13URCE/SPE-167042-MS/178424.

Yang Sheng, Harris, N.B., Dong Tian, Wu Wei, and Zhangxin Chen, 2018, Natural fractures and mechanical properties in a Horn River Shale core from well logs and hardness measurements: Society of Petroleum Engineers, SPE Reservoir Evaluation and Engineering, v. 21, no. 3, SPE-174287-PA, 12 p., accessed January 22, 2021, at https://onepetro.org/ REE/article-abstract/21/03/671/207347/Natural-Fractures-and-Mechanical-Properties-ina?redirectedFrom=fulltext.

Yousefzadeh, A., Qi, L., Virues, C., and Aguilera, R., 2016, Integrated interpretation of microseismic and petroleum engineering data for comparison of gas production in two interfering adjacent wellpads in the Horn River Basin, Canada, in Unconventional Resources Technology Conference (URTeC), San Antonio, Tex., August 1-3, 2016, Proceedings: Society of Exploration Geophysicists, American Association of Petroleum Geologists, Society of Petroleum Engineers, URTeC 2460254, 17 p., accessed January 22, 2021, at https://onepetro.org/URTECONF/proceedings-abstract/16URTC/ All-16URTC/URTEC-2460254-MS/152192.

\section{Horn River Basin-Cordova Embayment- Liard Basin Assessment Team}

Christopher J. Schenk, Tracey J. Mercier, Cheryl A. Woodall, Thomas M. Finn, Phuong A. Le, Michael E. Brownfield, Kristen R. Marra, Stephanie B. Gaswirth, Heidi M. Leathers-Miller, and Janet K. Pitman 